\section{SCIENCE IN PUBLIC SCHOOLS.}

THE seventeenth annual meeting of the Association of Public-School Science Masters was held at Eton College on January 3 and 4 . In his presidential address, Prof. H. H. Turner dealt with two main points, namely, that few boys have in them the making of scientific investigators, and that more openings are required for those who possess these attributes. Just as some boys have no sense of appreciation for music, so others are dead to scientific things, and may have a habitual dislike to them. It must, of course, be acknowledged that such types exist, but like indifference or antipathy can be found to all school subjects. Prof. Turner dealt with instruction in science as if its intention was to produce experts, whereas up to the age at which specialisation is permitted in a school course, the scientific teaching should be that which can claim a place in general education as justly as the teaching of letters, history, and mathematics. Boys who specialise in science afterwards may become investigators, but at present the careers open to them are few, and the prospects in them are unpromising. Prof. Turner suggested the formation of a Research Civil Service, parallel to the existing Administrative Civil Service. There is plenty of work to be done, such as the survey of our Empire, geodetically, magnetically, gravitationally, bathymetrically, and in other ways. There are forestry and fisheries, and industrial research of many kinds. Work is less likely to fail than workers. Modern researches are often of embarrassing length and involve much labour, but schools may help with some of them, and Prof. Turner gave a number of instances, of which "upper-air research" was one. He quoted Capt. Cave's opinion that such work is suitable for boys, and would be scientifically valuable. $\mathrm{Mr}$. O. H. Latter, of Charterhouse, in seconding a vote of thanks to the president, proposed by Mr. C. E. Ashford, of the Royal Naval College, Dartmouth, thought that the views of parents would have to be taken into consideration when contemplating purely scientific investigation in schools. In this connection he read the following letter received by him as typical of the attitude of many parents towards certain studies of natural history :-

"I wonder if I may ask your co-operation in regard to my son? I believe you are the principal natural science master, and that he has been under your tuition from time to time. The boy's extraordinary liking for what I regard as the most repulsive branch of natural history-newts, beetles, and insects-is a source of much disappointment both to his mother and to me. Can you either directly or indirectly turn his mind to a higher and more refined branch of the subject -birds, trees, or flowers? I cannot help feeling that the tendency of his present study is degrading, and I shall be glad to know if you think you can influence him in the wav I suggest. If you can, I shall be extremely grateful to you."

Prof. R A. Gregory, in opening a discussion on "Science for the Rank and File," said it is necessary to distinguish clearly between courses of work suitable for the rank and file and those intended as preliminary training for scientific or industrial careers. One has to do with science as an essential element of ' a liberal education; the other with vocational instruction. The former is at least as important as the latter, and little justification can be found for the concentrated attention given to a few subjects, with the view of imparting knowledge of experimental methods, when such a course means that the wonders of the fields beyond are kept outside the range of vision. For the imparting of the rudiments of a liberal education to all pupils the descriptive and qualitative school science of a NO. 2464 , VOL. 98$]$ generation ago is better adapted than the quantitative work in the narrow fields mapped out for instruction to-day. A plea was made for the introduction of descriptive lessons and reading intended to stimulate interest in scientific work and achievement and their relation to modern life, instead of limiting the teaching to dehumanised material of physics and chemistry.

Different aspects of this general subject of science for all were put forward in papers on :-A scheme of instruction in science for all boys throughout their school career, i.e. some science indispensable for all boys, by Mr. F. S. Young (Bishop's Stortford); the teaching of scienoe on the classical side, by the Rev. S. A. McDowall (Winchester); the áge for beginning serious science, by Mr. W. D. Eggar (Eton); classics the basis of a scientific education, by the Rev. A. L. Cortie, S.J. (Stonyhurst); how far can the advantages derived from teaching classics be denived from science? by the Rev. F. G. Forder (Charterhouse).

On the second day of the meeting, the first subject of discussion was technical bias in schools, and the papers read were:-School science in its relation to modern industrial problems, by Mr. E. R. Thomas (Rugby); school chemistry with a technical bias, by Mr. W. I. Gale (King's College School, Wimbledon); value and danger of giving a technical or topical trend to scientific education, by Mr. D. Berridge (Malvern). There was also a discussion on the place of text-books in science teaching, opened by Mr. G. N. Pingriff (University College School).

In the course of the discussion on technical bias in schools, Prof. A. Smithells said that in teaching science it should never be forgotten that however perfect might be the inculcation of scientific method, however sound the mental discipline, however powerful the in. tellectual weapon they supplied, unless they showed how science bore upon the environment and avocations of human life-unless, in fact, they humanised itscience could not flow effectually into the general culture of the nation.

Mr. C. L. Bryant, secretary of the association, in reading the report of the committee, said that towards the end of $x 9^{x} 5$ it was decided to arouse public opinion on the lack of appreciation of soience in this country, and as the result of the work of a sub-committee, $\mathrm{Mr}$. M. D. Hill was able to form what became known as the "Neglect of Science Committee." The committee of the association has also drawn up a memorandum containing $a$ statement of facts, prin. ciples, and policy, which served as a text for discussion between a deputation and the Govern. ment Committee on Science in Education. In view of the growing opinion that training in science forms an essential part of a liberal education, the com. mittee of the association has drafted a scheme of work which it considers to be suitable for all boys at the public schools up to the age of about sixteen and a half years. The meeting passed, nem. con., a motion expressing general approval of this scheme.

\section{FERTILISERS AND AGRICUL'URAL PRODUCTION.}

THE January issue of Blackwood's Magazine con. tains an important article by Prof. W. Somer. ville entitled "Increased Agricultural Production." As indicative of the present position of British agriculture, the author points out that of the food consumed we produce only one-fifth of the wheat, rather more than half the meat, one-quarter of the butter and margarine, one-fifth of the cheese, and nearly all the milk. The chief factor causing the reduction of the area of land tilled was the great increase in the 
amount of wheat imported from North America in the 'seventies and 'eightres. In the past forty-three years Great Britain has lost $3 \frac{1}{2}$ million acres of tillage crops, including $1 \frac{1}{2}$ million acres of wheat, and has produced no more meat, although the milk production has doubtless increased. This fact supports the contention that the area of land under crops may be largely increased without any decrease of stock-keeping.

After contrasting the English and German increase in food-production in the past forty years as shown by the recent Memorandum of the Board of Agriculture, and summarising the recommendations of the English, Scottish, and Irish Committees for increased food production during the war, Prof. Somerville urges that the post-war problem of a large permanent increase in food production is the more difficult to solve. The solution of the problem is complicated by the consideration that if a durable peace is obtained there will be a long period available for the reconstruction of our agriculture, whilst if only an "armed" peace results from the present conflict, rearrangement will be necessary in the shortest possible time. Given that it is desirable to secure an increase of a million acres of wheat, many consider that this could be effected by guaranteeing a minimum price, which presumably would have to be extended to oats as well as to wheat, since the latter is of quite subordinate importance. in Scotland and Ireland.

A. rather more attractive suggestion is that farmers should be granted a bonus on the area of grass land converted to arable: this has recently been adopted in France. But there is one way in which an immediate and large increase in production can be effected, namely, by using on British land the whole of the ammonium sulphate produced in this country. Of the 400,000 tons of this fertiliser annually produced, 294,000 tons were exported in 1915, and for 19.16 the amount was probably about 250,000 tons. If the latter were used on one-fourth of the area under wheat, oats, roots, potatoes, and hay, it would only give $60 \mathrm{lb}$. to the acre. Representing sulphate of ammonia in terms of wheat. the amount exported in 1916 is equivalent to $2 \frac{1}{2}$ million quarters of wheat-i.e. an addition of more than 30 per cent. to our present home-grown supply. Further, the exportation of fertiliser and importation of wheat require shipping to the extent of 800,000 tons, and result in an adverse trade balance of $4,575,000 l$.

The case for prohibiting the export of ammonium sulphate is enormously strengthened by the reduction in the import of sodium nitrate in r916. Since the latter decrease has not been compensated for by increased use of sulphate of ammonia, the land must have suffered a reduction in fertilitv. The 40,000 tons of basic slag exported in I9I6 could be used on British land even more easily than the ammonium sulphate. It would suffice to produce $3,200,000^{\circ} 1 \mathrm{~b}$. of meat annually for five years, and here again considerations of freight and exchange are in favour of prohibited export. The use of basic slag on second-rate and inferior pastures is the most certain way of increasing production of food, and it is important now, because it involves only a fraction of the man and horse labour necessary for tillage.

Prof. Somerville is of the opinion that some measure of compulsion, will be necessary, and advocates the establishment of local committees to decide which farms can make best use of the sulphate of ammonia and basic slag available, and which grass lands are to be tilled. Although recognising their obvious advantages, he considers that the creation of small holdings would prove more a hindrance than a help in regard to the production of the major part of the people's food.

$$
\text { NO. 2464, VOL. } 98]
$$

\section{ITALIAN METEOROLOGY. ${ }^{1}$}

A NUMBER of useful meteorological memoirs by Prof. Eredia, of the Central Meteorological and Geophysical Institute of Rome, deal with various aspects of the meteorology of Italy. No. I is the Italian meteorological observers' handbook, copiously illustrated, in which full instructions are given regarding the installation of instruments for a normal station, along with practical hints regarding its maintenance. Instructions are also given for the taking of phenological observations. "The Variation of the Climate in Italy " (No. 2) is a reprint of a paper read at the tenth International Geographical Congress held in Rome during 1913 , in which the mean annual temperature from 1866 to I9Io at sixteen stations is discussed. The warmest year was 1879 , except in the insular areas, while 1900 was the coldest. The temperature variations, it may be said, are in general the reverse of those in the British Isles. Fog frequency over the region embraced by Lombardy, Venetia, and Emilia; based on data for twenty-three stations over the period 1892-I9I4, forms the subject-matter of No. 3. From May to August there are few fogs, the maximum taking place in winter Maps of fog frequency are given for the autumn, winter, and for the year, while several isobaric charts indicate the conditions associated with some winter fogs.

The storm of October 7 , I9I5, along with a synopsis of storm frequency at the Tripoli Observatory from 1892 to 1914 , is dealt with in No. 4. Isobaric charts referring to 8 a.m. and 9 p.m. illustrate the progress of the October storm. At Tripoli during the twentythree years under consideration I64 storms were observed, the greatest number recorded being twenty in 1906, and the least number two in I9I3 and 19I4. The frequency by seasons shows that autumn is the stormiest time of the year with sixty-nine instances, followed by spring with forty-five, winter with thirtythree, while in summer only seventeen were noted. The diurnal period shows a maximum in the three hours ending 9 p.m., when storms are six times more numerous than in the three hours ending with 3 p.m. The rainfall associated with the storms discussed is small. In forty-five cases none was measured, and in forty-one other cases less than $5 \mathrm{~mm}$. fell. In nineteen instances the fall exceeded $20 \mathrm{~mm}$. A general review of the various drosometers hitherto employed for the registration of the amount of dew is given in No. 5, along with a description of a new form employed by the institute, which has many features to recommend it.

R. C. M.

\section{ETHNOBOTANY OF AMERICAN INDIANS}

$\mathrm{N}$ the thirtieth annual report of the Bureau of American Ethnology, Mr. M. C. Stevenson publishes an elaborate article on the ethnobotany of the Zuni Indians. This tribe had discovered the medicinal value of a large number of plants, one of the most important of which is the Jamestown weed (Datura meteloides), and the writer observes that from the symptoms caused by this drug, its homœeopathic adaptability to hydrophobia will be at once evident. "There is no drug so far proven that deserves as thorough and careful a trial in this dread disease as stramonium." "They learned the value of Datura meteloides as a narcotic perhaps centuries before the birth of Baron Stoerck, of Vienna, who first brought it to the atten-

1 (r) "Norme per l'impianto e per il funzionamento della stazioni terminudometriche:" $\mathrm{Pp.} 4 \mathrm{I}$. (Rome, 1916.) (2) "Le variazioni del clima in udometriche." Pp. 41. (Rome, 1916.) (2) "Le variazioni del clima in charts. (Rome, r9r6.) (4) "Sul temporale verificatori a Tripoli nell

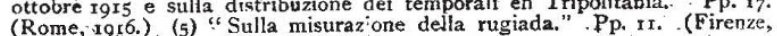
(Ror.) 